\title{
REVIEW JURNAL: PEMANFAATAN ETOSOM SEBAGAI BENTUK SEDIAAN PATCH
}

\section{JOURNAL REVIEW: UTILIZATION THE ETHOSOME AS A PHARMACEUTICAL PATCH}

\author{
Rina Andriani', Muhammad Hajrul Malaka', Irmayani Jubir ${ }^{1}$, Vica Aspadiah', \\ Adryan Fristiohady ${ }^{1 *}$
}

\author{
${ }^{1}$ Jurusan Farmasi, Fakultas Farmasi, Universitas Halu Oleo, Kendari
}

Naskah diterima tanggal 15 Januari 2021

\begin{abstract}
Ethosome is delivery system in the form of soft and elastic vesicles with the main components, namely phospholipids, alcohol with a high enough concentration (2045\%), and water. Ethosomes can increase drug penetration further into the skin due to the presence of phospholipids and ethanol. Ethosomes can also deliver drugs to reach the systemic circulation so they are very suitable as a carrier for transdermal preparations, especially patches. The use of ethosomes in transdermal patch preparations can increase the penetration, permeability, and bioavailability of a drug. This review provides information on the use of ethosomes as a pharmaceutical patch.
\end{abstract}

Keywords: Ethosome, Patch, Transdermal

\begin{abstract}
ABSTRAK
Etosom merupakan suatu sistem pembawa berupa vesikel yang lunak dan elastis dengan komponen utama yaitu fosfopilid, etanol dengan konsentrasi yang cukup tinggi (20-45\%), dan air. Etosom memiliki kemampuan dalam meningkatkan penetrasi obat lebih jauh ke dalam kulit dikarenakan adanya kandungan fosfolipid dan etanol. Etosom juga dapat menghantarkan obat hingga mencapai sirkulasi sistemik sehingga sangat cocok digunakan sebagai sistem pembawa yang diformulasikan kedalam bentuk sediaan, salah satunya sediaan patch transdermal. Penggunaan etosom dalam sediaan patch transdermal dapat meningkatkan kemampuan penetrasi, permeabilitas dan bioavailabilitas dari suatu obat. Review ini memberikan informasi mengenai pemanfaatan etosom sebagai bentuk sediaan patch.
\end{abstract}

Kata Kunci : Etosom, Patch, Transdermal

\section{PENDAHULUAN}

Kulit adalah salah satu organ tubuh manusia yang paling luas dan mudah diakses sebagai tempat penghantaran obat dan menawarkan banyak keuntungan. Salah satu Keuntungannya yaitu lutit relatif permeabel terhadap senyawa-senyawa kimia dan dapat ditembus oleh senyawa obat yang dapat menimbulkan efek terapeutik, baik yang bersifat lokal maupun sistemik (Shukla et al., 2016). Luas kulit rata-rata orang dewasa adalah sekitar $2 \mathrm{~m}^{2}$ dan diperkirakan mencapai $16 \%$ dari total berat tubuh manusia. Oleh karena itu, kulit dapat menjadi target masuknya obat dari sediaan topikal. Transdermal Drug Delivery System

Alamat korespondensi :

adryanfristiohady@uho.a.id
(TDDS) merupakan sistem penghantaran obat yang menghantarkan obat ke kulit dengan kecepatan tertentu untuk mencapai efek sistemik (Patrekar et al., 2015; Prasanthi dan Lakshmi, 2012).

Penghantaran obat secara transderma! memiliki banyak keuntungan seperti memberikan pelepasan obat yang terkontrol dan konstan, mudah digunakan, mengurangi efek samping obat seperti iritasi lambung, meningkatkan bioavaibilitas obat yang rendah, dan menghindari first-pass effect. Selain itu sediaan transdermal juga dapat memberikan efek terapi yang lama dengan sekali pemakaian sehingga akan meningkatkan kenyamanan pasien bila dibandingkan dengan sediaan lainnya yang memerlukan pemberian yang sering untuk mencapai dosis terapi (Arifin dkk., 2019, Bodade 
et al., 2013; Ramadhani dkk., 2017; Ma et al., 2018).

Sistem transdermal biasanya dibuat dalam bentuk sediaan patch atau sediaan semisolid misalnya gel, salep, atau krim (Akib dkk., 2014). Sistem penghantran obat transdermal dapat dirancang untuk menghantarkan obat dengan mempertahankan tingkat kadar plasmanya agar memiliki efek terapeutik, menghantarkan obat tanpa penghantaran berkala serta memungkinkan penghantaran obat ke dalam sirkulasi sistemik dengan cara permeasi melalui lapisan kulit (Prabhakara et al., 2010).

Penghantaran obat dengan sistem transdermal memiliki mekanisme yaitu partikel obat akan dihantarkan melalui barrier utama kulit yaitu lapisan stratum korneum dengan cara berdifusi melalui molekul lipid (Arifin dkk., 2019). Saat ini, transdermal merupakan salah satu penelitian yang banyak dilakukan dalam sistem penghantaran obat karena efeknya telah sebanding dengan pemberian obat melalui peroral (Akib dkk., 2014). Salah satu bentuk sediaan transdermal yang saat ini banyak diteliti karena memiliki banyak keuntungan dalam menghantarkan obat ke tempat aksi adalah sediaan patch (Ermawati dan Heni, 2019).

Patch transdermal merupakan sediaan yang memiliki perekat dan di dalamnya mengandung molekul obat, dimana penggunannya dengan cara ditempelkan ke kulit agar dapat melepaskan obat dalam dosis tertentu. Patch transdermal melepaskan obat secara terkontrol sehingga obat dapat terdistribusi dalam saluran sistemik (Rahim dkk., 2016; Purnamasari dkk., 2019). Patch transdermal pertama adalah Transderm-Scop (scopolamine) yang dikembangkan oleh ALZA Corporation (USA) dan telah disetujui oleh FDA pada tahun 1981 untuk perawatan mabuk dan selanjutnya diikuti oleh patch nitrogliserin yang digunakan untuk perawatan angina pektoris (Singh dan Alka, 2016).

Sediaan patch yang baik harus memenuhi karakteristik fisik antara lain fleksibel, homogen, tipis, dan halus. Komponen utama dari patch adalah polimer yang berfungsi untuk mengontrol pelepasan obat. Kemampuan pelepasan obat dari polimer merupakan hal yang sangat mempengaruhi keberhasilan sediaan patch dalam menghantarkan obat. Terdapat dua tipe sistem patch transdermal yaitu tipe membran atau reservoir dan tipe matrik atau monolitik. Pada sistem matrik, polimer akan berikatan dengan molekul obat dan mengendalikan laju pelepasannya (Hendradi dkk., 2011).

Salah satu pembawa yang bisa digunakan untuk pembuatan sediaan patch adalah etosom. Etosom pertama kali dikembangkan oleh Touitou dan rekannya pada tahun 1997. Etosom adalah salah satu sistem pembawa berupa vesikel dengan karakteristik lembut dan elastis yang komponen utamanya adalah fosfopilid, etanol dan air, dimana konsentrasi etanol yang cukup tinggi yaitu berkisar antara $20-45 \%$. Fosfolipid yang bisa digunakan dalam pembuatan etosom sangat beragam. Beberapa fosfolipid yang biasa digunakan yaitu fosfatidilkolin atau fosfatidiletanolamin dengan konsentrasi $0,5-10 \%$ (Ramadon dan Abdul, 2016).

Sifat fisikokimia dari etosom dapat dijadikan sebagai pembawa untuk menghantarkan zat aktif melalui kulit jauh lebih unggul baik secara jumlah maupun kedalaman ketika dibandingkan dengan liposom (Ramadon dan Abdul, 2016). Saat ini etosom sangat banyak dikembangkan khususnya untuk peningkatkan penetrasi dari senyawa bahan alam. Etosom juga merupakan pembawa yang sangat baik untuk sediaan patch karena dapat meningkatkan bioavailabilitas dari zat aktif yang dapat mempengaruhi keberhasilan terapi. Review ini bertujuan untuk mengetahui penggunaan etosom sebagai pembawa dalam sediaan patch yang memiliki peran penting dalam menghantarkan suatu zat aktif.

\section{METODE}

Data yang digunakan dalam penulisan review jurnal ini dikumpulkan menggunakan metode studi pustaka. Penelusuran pustaka dilakukan menggunakan instrumen pencarian pustaka berbasis online, seperti Google, Google Scholar, NCBI-PubMed, Research Gate dan Elsevier. Kata kunci yang digunakan dalam penelusuran pustaka terkait dengan "pemanfaatan etosom sebagai sediaan patch", "patch etosom", "etosom sebagai sistem penghantaran obat" "formulasi patch etosom transdermal", "utilization ethosome as a patch preparation", "ethosome patch "transdermal patch ethosome". Pustaka yang diperoleh kemudian disusun sesuai kerangka pemanfaatan etosom sebagai bentuk sediaan patch dan penulisan review jurnal sesuai format yang diberikan. Berdasarkan hasil studi literatur, diperoleh 42 jurnal yang terdiri atas 29 jurnal internasional dan 13 jurnal nasional yang memuat informasi mengenai pemanfaatan etosom sebagai bentuk sediaan patch.

\section{PEMBAHASAN}

Etosom merupakan sistem vesikuler yang menarik dan inovatif sebagai pembawa obat yang telah muncul di bidang teknologi farmasi dalam beberapa tahun terakhir (Dave et al., 2010). Etosom adalah vesikel berbasis lipid yang mengandung fosfolipid, etanol dalam konsentrasi 
yang relatif tinggi dan air. Adanya fosfolipid dan etanol pada etosom telah dilaporkan dapat meningkatkan permeasi dan penetrasi obat lebih dalam pada lapisan kulit (Kumar dan Patra, 2020; Limsuwan et al., 2017). Etosom memiliki ukuran vesikel etosom yang bervariasi, mulai dari mikrometer $(\mu \mathrm{m})$ hingga nanometer $(\mathrm{nm})$. Ukurannya bergantung pada komposisi, metode pembuatan serta teknik penggunaan alat misalnya sonikator (Ramadon dan Abdul, 2016). Struktur etosom berupa vesikel lipid bilayer dengan celah di bagian inti seperti yang terlihat pada Gambar 1.

Etosom mampu meningkatkan penghantaran molekul obat melalui kulit baik secara in vitro maupun in vivo (Prasanthi dan Lakshmi, 2012). Etosom secara signifikan dapat meningkatkan nilai fluks sediaan transdermal serta dapat mengatasi efek samping obat berupa iritasi pada saluran pencernaan jika diberikan secara oral. Jika dibandingkan dengan vesikel pembawa lainnya etosom memiliki beberapa keunggulan dan kekurangan (Ramadon dan Abdul, 2016; Akib dkk., 2014)

Kelebihan etosom dibandingkan dengan vesikel pembawa lainnya yaitu etosom dapat meningkatkan penetrasi molekul obat melalui kulit baik untuk rute dermal ataupun transdermal (Ramadon dan Abdul, 2016; Bragagni et al., 2012), etosom dapat menghantarkan molekul obat dengan sifat fisikokimia yang beragam, mulai dari senyawa yang bersifat hidrofilik, lipofilik, maupun makromolekul lainnya (Rakesh dan Anoop, 2012), komponen- penyusun etosom terbukti aman dan telah disetujui FDA untuk digunakan pada sediaan farmasi dan kosmetik, umumnya etosom diformulasikan dalam bentuk sediaan patch dan semisolid (gel atau krim) sehingga dapat meningkatkan kepatuhan pasien (Pandey et al., 2015), etosom meningkatkan penghantaran obat pada kulit baik dalam kondisi oklusif dan non-oklusif (Wahid et al., 2011), ukuran etosom relatif lebih kecil dibandingkan vesikel obat konvensional, etosom dapat meningkatkan permeasi obat karena dapat membawa obat melewati stratum korneum menuju lapisan kulit yang lebih dalam (Salmannejad et al., 2015; Gaikwad dan Ayushi,
2017), etosom dapat diformulasikan dengan mudah dan tidak memerlukan peralatan canggih atau peralatan yang dirancang khusus (Rakesh dan Anoop, 2012).

Etosom juga memiliki beberapa kekurangan dibanding vesikel pembawa lain, yaitu kemampuan etosom dalam menjerap obat masih dalam jumlah terbatas dan hanya dapat membawa obat dengan dosis harian yang rendah, sehingga biasanya dirancang untuk melepaskan obat secara lambat dan berkelanjutan (Ramadon dan Abdul, 2016; Zahid et al., 2018), ukuran molekul obat yang akan dihantarkan oleh etosom harus sangat kecil sehingga dapat diabsorbsi, etosom tidak melekat dengan baik pada beberapa jenis kulit dan etosom dapat menyebabkan dermatitis akibat penambahan eksipien lain. Selain itu, salah satu komponen etosom yaitu fosfolipid harganya kurang ekonomis (Mohanty et al., 2018; Jaiswal et al., 2016).

Etosom dapat digunakan sebagai pembawa dalam sediaan patch transdermal. Patch dengan pembawa etosom memiliki beberapa keunggulan dibandingkan dengan gel dan krim etosom yaitu patch etosom dapat diberikan dalam kondisi oklusif maupun nonoklusif sehingga permeasi yang diharapkan lebih banyak. Faktor yang paling penting untuk dipertimbangkan dalam formulasi patch etosom adalah sifat fisikokimia dari obat/agen terapeutik yang akan digunakan. Hal ini dikarenakan agen terapeutik dapat mempengaruhi sifat-sifat sistem etosom, terutama ukuran partikel dan zeta potensial (Abdulbaqi et al., 2016).

\section{Komponen Etosom}

Komponen utama etosom adalah fosfopilid, etanol dan air, dengan konsentrasi etanol yang relatif tinggi. Etosom dapat mengandung fosfolipid dengan berbagai struktur kimia (seperti fosfatidilkolin dan asam fosfatidat), etanol atau isopropil alkohol, air dan propilen glikol (atau glikol lainnya). Selain itu, surfaktan non-ionik (PEG-alkil eter) dan lipid kationik dapat dikombinasikan dengan fosfolipid dalam sediaan. Konsentrasi fase tidak berair (alkohol dan kombinasi glikol) dapat berkisar antara 22 hingga
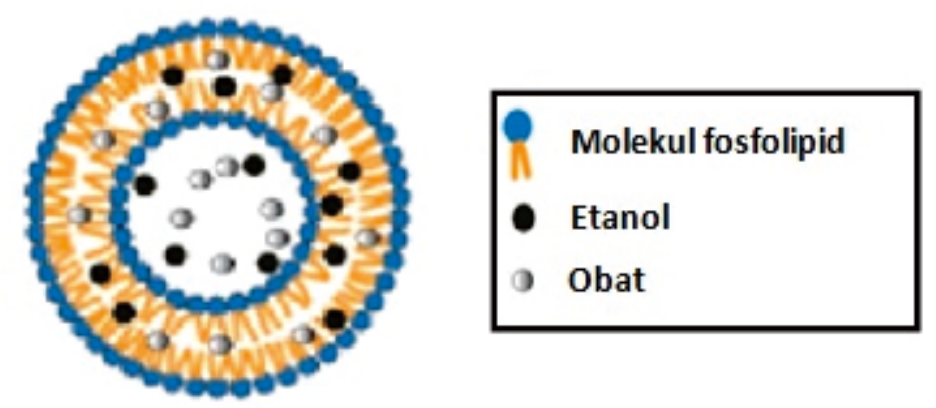

Gambar 1. Struktur Etosom (Abdulbaqi dkk., 2016) 
70\% (Zahid et al., 2018; Rakesh dan Anoop, 2012).

1. Etanol

Etanol dalam etosom berfungsi sebagai zat yang membuat membran vesikel menjadi halus dan juga sebagai peningkat penetrasi (Jaiswal et al., 2016). Sebagai peningkat penetrasi, etanol akan membasahi lapisan ganda lipid dari vesikel etosom dan stratum korneum secara bersamaan, sehingga vesikel etosom yang sangat lunak akan menembus struktur stratum korneum (Abdulbaqi et al., 2016). Rumus struktur etanol dapat dilihat pada Gambar 2.

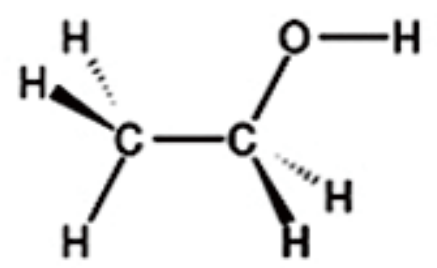

\section{Gambar 2. Rumus Struktur Etanol (Wusnah dkk., 2016)}

\section{Fosfolipid}

Fosfolipid dalam etosom berfungsi sebagai komponen pembentuk vesikel (Jaiswal et al., 2016). Fosfolipid juga dilaporkan bertindak secara sinergis dengan etanol untuk meningkatkan permeasi obat dalam formulasi etosom (Abdulbaqi et al., 2016). Beberapa contoh fosfolipid yang biasa digunakan dalam pembuatan etosom antara lain asam fosfatidat,<smiles>CC(O)CO</smiles><smiles>CCOCCOCCO</smiles>

Gambar 4. Rumus Struktur (1) Propilen Glikol dan (2) Dietilen Glikol Monoetil Eter (Fiume dkk., 2012).

fosfatidilkolin, fosfatidiletanolamin, fosfatidilinositol, fosfatidilserin dan fosfatidilgliserol (Zahid et al., 2018). Rumus struktur fosfolipid tersebut dapat dilihat pada Gambar 3.

\section{Poliglikol}

Poliglikol biasa ditambahkan dalam pembuatan etosom, tetapi sangat jarang. Jika ditambahkan ke dalam etosom, poliglikol berfungsi sebagai zat peningkat penetrasi pada kulit. Contoh poligikol yaitu propilen glikol dan dietilen glikol monoetil eter (Jaiswal et al., 2016). Rumus struktur propilen glikol dan dietilen glikol monoetil eter dapat dilihat pada Gambar 4.

\section{Jenis-Jenis Sistem Etosom}

Etosom pada umumnya terdiri atas fosfolipid, etanol dan air. Penambahan bahan lain seperti propilenglikol dan surfaktan dapat menjadikan etosom menjadi beberapa jenis yang berbeda. Berdasarkan komposisi, etosom dapat diklasifikasikan menjadi etosom klasik, etosom biner dan transetosom. Struktur dari ketiga jenis

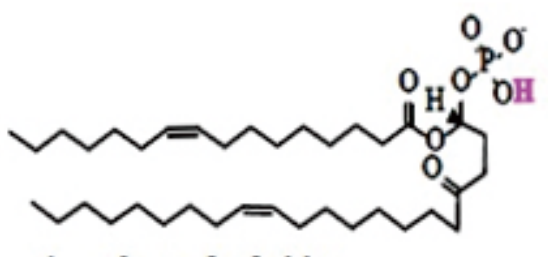

1 Asam fosfatidat
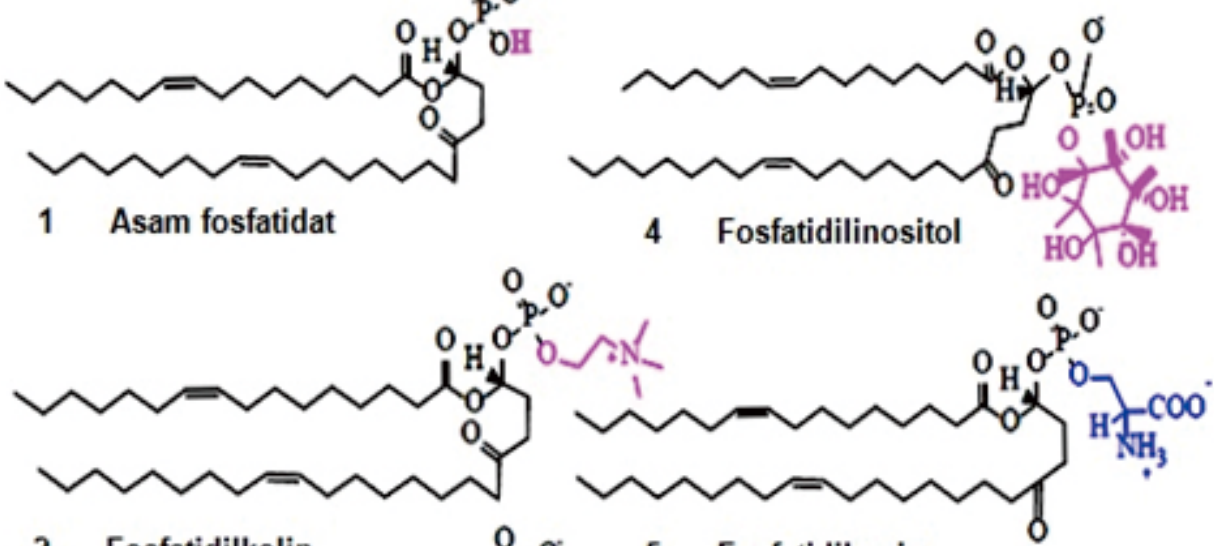

2 Fosfatidilkolin

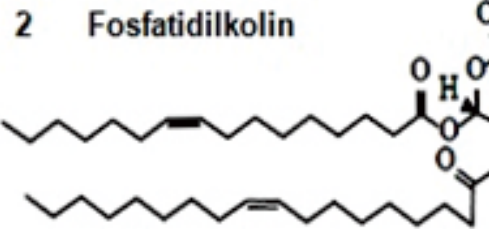

3 Fosfatidiletanolamin
5 Fosfatidilserin

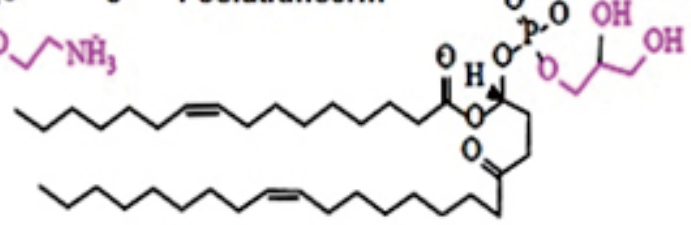

6 Fosfatidilgliserol

Gambar 3. Rumus Struktur Fosfolipid (Alagumuthu dkk., 2019) 


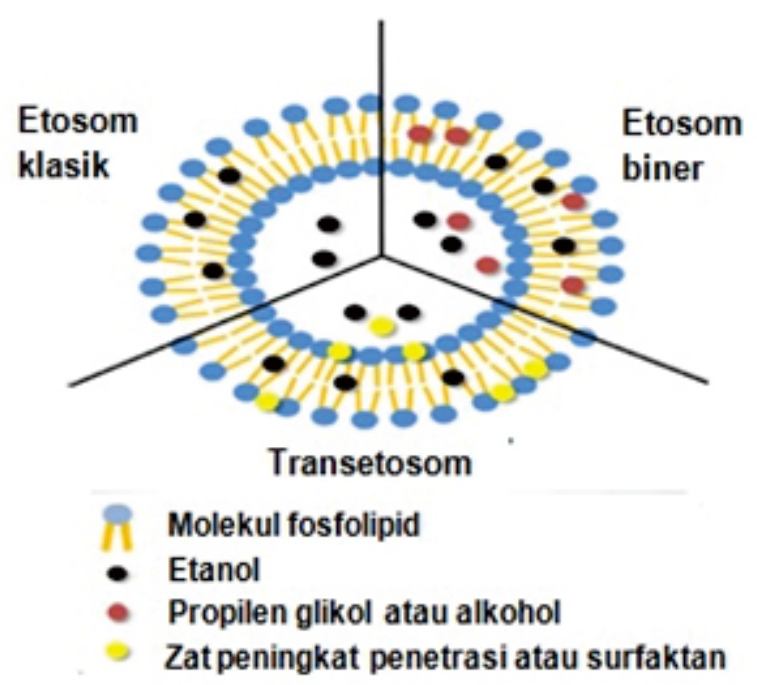

Gambar 5. Jenis Sistem Etosom (Abdulbaqi dkk., 2016)

etosom dapat dilihat pada Gambar 5.

\section{Etosom klasik}

Etosom klasik adalah modifikasi dari liposom klasik dan terdiri dari fosfolipid, etanol konsentrasi tinggi hingga $45 \% \mathrm{~b} / \mathrm{b}$, dan air.
Etosom klasik dilaporkan lebih unggul daripada liposom klasik untuk penghantaran obat karena memiliki ukuran yang lebih kecil. Selain itu, etosom klasik menunjukkan tingkat permeasi kulit dan profil stabilitas yang lebih baik dibandingkan dengan liposom klasik (Mohanty et al., 2018).

\section{Etosom biner}

Etosom biner dikembangkan dengan menambahkan alkohol jenis lain atau propilen glikol ke dalam etosom klasik. Tingkat permeasi etosom biner pada kulit hampir sama dengan etosom klasik. Alkohol yang paling umum digunakan dalam etosom biner adalah isopropil alkohol (IPA) (Abdulbaqi et al., 2016).

\section{Transetosom}

Sistem etosom ini mengandung komponen dasar etosom klasik dan bahan tambahan, seperti zat peningkat penetrasi atau surfaktan. Vesikel-vesikel transetosom dikembangkan sebagai upaya untuk menggabungkan keunggulan etosom klasik dan liposom yang dapat diubah bentuk (transferom). Tipe transetosom memiliki sifat permeasi kulit yang unggul dibandingkan etosom klasik, karena
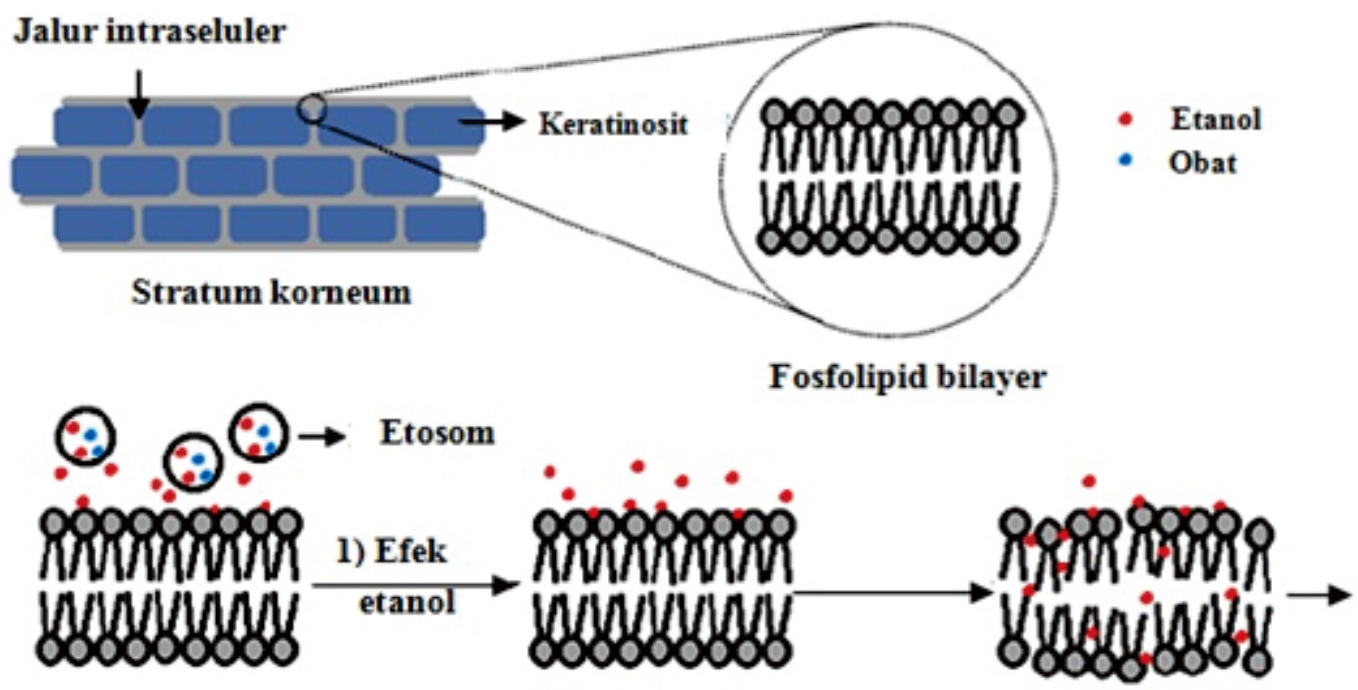

Interaksi etanol dengan molekul lipid stratum korneum
Etanol menembus molekul lipid pada stratum korneum

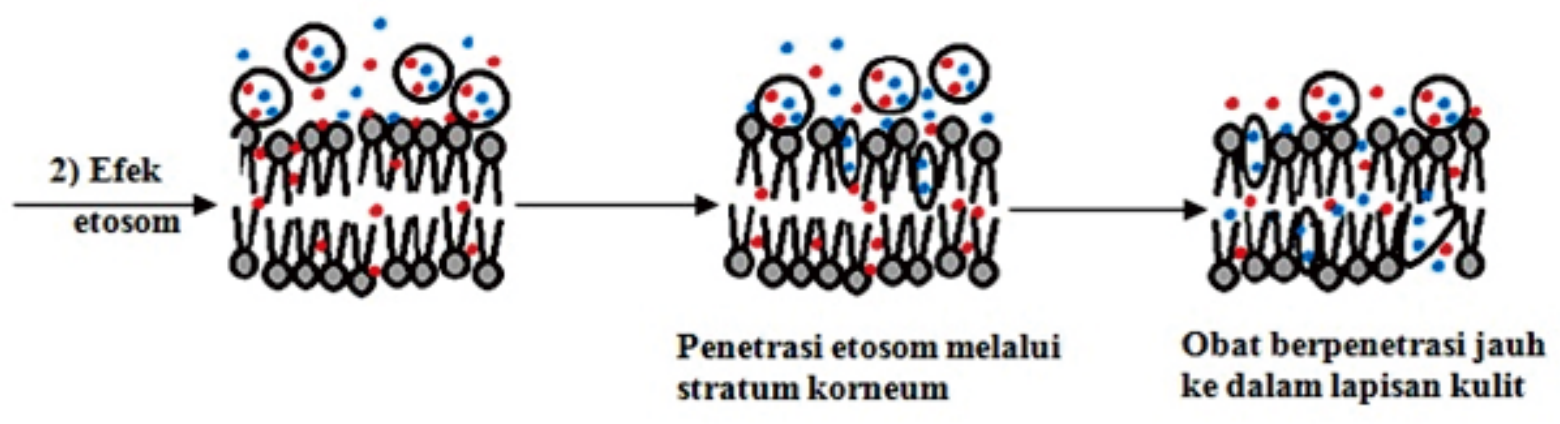

Gambar 6. Mekanisme Penetrasi Etosom pada Kulit (Rakesh dan Anoop, 2012) 
Tabel 1. Perbandingan Etosom Klasik, Etosom Biner, dan Transetosom (Abdulbaqi dkk., 2016)

\begin{tabular}{|c|c|c|c|}
\hline Parameter & Etos om Klasik & Etosom Biner & Transetosom \\
\hline Komposisi & $\begin{array}{l}\text { 1. Obat/agen } \\
\text { terapeutik } \\
\text { 2. Fosfolipid } \\
\text { 3. Etanol } \\
\text { 4. Air }\end{array}$ & $\begin{array}{l}\text { 1. Obat/agen } \\
\text { terapeutik } \\
\text { 2. Fosfolipid } \\
\text { 3. Etanol } \\
\text { 4. Propilen glikol atau } \\
\text { alkohol lainnya } \\
\text { 5. Perekat } \\
\text { 6. Air }\end{array}$ & $\begin{array}{l}\text { 1. Obat/agen terapeutik } \\
\text { 2. Fosfolipid } \\
\text { 3. Etanol } \\
\text { 4. Surfaktan atau zat } \\
\text { peningkat penetrasi } \\
\text { 5. Perekat } \\
\text { 6. Air }\end{array}$ \\
\hline Morfologi & Bulat & Bulat & $\begin{array}{l}\text { Bulat teratur atau tidak } \\
\text { teratur }\end{array}$ \\
\hline Ukuran & $\begin{array}{l}\text { Lebih kecil dari } \\
\text { liposom klasik }\end{array}$ & $\begin{array}{l}\text { Sama dengan atau } \\
\text { lebih ke cil dari etosom } \\
\text { klasik }\end{array}$ & $\begin{array}{l}\text { Ukuran berdasarkan } \\
\text { jenis dan konsentras } \\
\text { Surfaktan atau zat } \\
\text { peningkat penetrasi } \\
\text { yang digunakan }\end{array}$ \\
\hline Zeta potensial & Bermuatan negatif & Bermuatan negatif & $\begin{array}{l}\text { Bermuatan positif atau } \\
\text { negatif }\end{array}$ \\
\hline Efisiensi & $\begin{array}{l}\text { Lebih tinggi dari } \\
\text { liposom klasik }\end{array}$ & $\begin{array}{ll}\text { Biasanya } & \text { lebih tinggi } \\
\text { daripada } & \text { etosom } \\
\text { klasik } & \end{array}$ & $\begin{array}{l}\text { Biasanya lebih tingg } \\
\text { daripada etosom klasik }\end{array}$ \\
\hline Permeasi kulit & $\begin{array}{l}\text { Biasanya lebih tinggi } \\
\text { dari liposom klasik }\end{array}$ & $\begin{array}{l}\text { Biasanya sama atau } \\
\text { lebih tinggi dari } \\
\text { eto som klasik }\end{array}$ & $\begin{array}{l}\text { Biasanya lebih tingg } \\
\text { daripada etosom klasik }\end{array}$ \\
\hline Stabilitas & $\begin{array}{l}\text { Lebih } \\
\text { dibandingkan liposom } \\
\text { klasik }\end{array}$ & $\begin{array}{l}\text { Lebih stabil daripada } \\
\text { eto som klasik }\end{array}$ & $\begin{array}{l}\text { Kecenderungan } \\
\text { stabilitas partikel tidak } \\
\text { ditentukan }\end{array}$ \\
\hline
\end{tabular}

mengandung etanol dan surfaktan atau zat peningkat penetrasi yang dapat meningkatkan eleastisitas etosom (Mohanty et al., 2018; Sultana et al., 2018).

Perbedaan komposisi etosom juga dapat mempengaruhi sifat-sifat lain dari etosom, seperti morfologi, ukuran, maupun stabilitas etosom. Perbedaan etosom klasik, etosom biner dan transetosom dapat dilihat pada Tabel 1.

\section{Mekanisme Penetrasi dan Permeasi Etosom pada Kulit}

Etosom sebagai pembawa dapat meningkatkan permeasi dan penetrasi yang lebih dalam pada lapisan kulit dikarenakan adanya kandungan fosfolipid dan konsentrasi etanol yang tinggi pada etosom. Mekanisme penetrasi etosom dapat dilihat pada Gambar 6 .

Etanol dan fosfolipid dilaporkan bekerja secara sinergis untuk meningkatkan penetrasi zat aktif ke dalam kulit (Abdulbaqi et al., 2016). Adanya etanol dalam etosom menyebabkan deformabilitas vesikel meningkat. Vesikel pada etosom yang terdeformasi akan masuk ke dalam stratum korneum dan akhirnya melepaskan obat di lapisan kulit yang lebih dalam. Mekanisme penetrasi etosom melibatkan dua efek yaitu efek etosom dan efek etanol pada lapisan stratum korneum (Zahid et al., 2018).

\section{Efek etanol}

Mekanisme efek peningkatan penetrasi etosom melalui telah dikenal secara luas (Zahid et al., 2018). Etanol akan menembus ke dalam lipid antar sel dengan cara meningkatkan fluiditas lipid membran sel dan menurunkan kepadatan molekul lipid multilayer dari membran sel. Vesikel etosom yang sangat lunak kemudian akan menembus struktur stratum korneum dan epidermis lainnya sehingga zat aktif dapat berpenetrasi jauh ke dalam lapisan kulit dan menghasilkan efek sistemik (Abdulbaqi et al., 2016).

\section{Efek etosom}

Fleksibilitas dari vesikel etosom menyebabkan adanya interaksi antara etosom dengan lapisan lipid ganda pada stratum korneum dan bahkan membentuk jalur penetrasi melalui kulit berdasarkan sifat dari partikelnya. 
Peningkatan fluiditas lipid pada membran sel yang disebabkan oleh etosom akan menghasilkan peningkatan permeabilitas kulit. Sehingga etosom dengan sangat mudah menembus lapisan kulit yang dalam karena menyatu dengan lipid yang ada pada kulit. Hal ini menyebabkan obat berpenetrasi jauh ke dalam lapisan kulit (Rakesh dan Anoop, 2012; Zahid et al., 2018).

\section{Metode Preparasi Etosom}

Etosom dapat disiapkan dengan beberapa metode diantaranya sebagai berikut:

\section{Metode dingin}

Preparasi etosom menggunakan metode dingin diawali dengan melarutkan fosfolipid, zat aktif dan bahan yang bersifat lipid lainnya dengan etanol di dalam bejana tertutup, pada suhu kamar dan dengan pengadukan kuat (menggunakan mixer). Propilen glikol atau poliol lainnya ditambahkan selama proses pengadukan. Campuran ini dipanaskan hingga $30^{\circ} \mathrm{C}$ di atas waterbath. Campuran ditambahkan air yang dipanaskan hingga $30^{\circ} \mathrm{C}$ dalam bejana terpisah, kemudian diaduk selama 5 menit dalam wadah tertutup. Ukuran vesikel formulasi etosom dapat diturunkan sesuai keinginan menggunakan metode sonikasi. Etosom yang telah jadi formulasi disimpan pada refrigerator (kulkas) (Mohanty et al., 2018).

\section{Metode panas}

Metode ini diawali dengan mendispersikan fosfolipid ke dalam air dengan cara memanaskannya dalam waterbath pada suhu $40^{\circ} \mathrm{C}$ hingga diperoleh cairan koloid. Pada bejana yang terpisah, etanol dan propilen glikol dicampur dan dipanaskan hingga $40^{\circ} \mathrm{C}$. Kedua campuran dicampur pada suhu $40^{\circ} \mathrm{C}$ (fase organik ditambahkan ke fase air). Setelah itu zat aktif dilarutkan dalam air atau etanol, tergantung pada sifat hidrofilik/hidrofobiknya. Ukuran vesikel formulasi etosom dapat diturunkan sesuai keinginan menggunakan metode sonikasi (Mohanty et al., 2018). Setelah melalukan sonikasi, dapat dilakukan homogenisasi dengan tekanan tinggi untuk mendapatkan etosom yang berukuran nanometer (Thadanki dan Babu, 2015).

\section{Metode injeksi}

Preparasi etosom menggunakan metode ini diawali dengan melarutkan fosfolipid dan obat ke dalam etanol dan propilen glikol hingga terbentuk vesikel kemudian dipanaskan campuran pada suhu $30^{\circ} \mathrm{C}$ dalam waterbath. Campuran ditambahkan air sedikit demi sedikit dan diaduk dengan kecepatan 700 rpm selama 5 menit pada suhu $30^{\circ} \mathrm{C}$. Dilakukan sonikasi sebanyak 3 siklus selama 5 menit, istrahat pada setiap siklus. Formula dimasukkan ke dalam dan disimpan pada suhu $4^{\circ} \mathrm{C}$ (Jaiswal et al., 2016).

\section{Metode optimasi (metode hidrasi film)}

Metode optimasi untuk preparasi etosom diawali dengan melarutkan fosfolipid dalam campuran pelarut kloroform:metanol dengan perbandingan 3:1 di dalam labu alas bulat kemudian diuapkan menggunakan rotary evaporator di atas suhu transisi lipid yaitu di atas $60^{\circ} \mathrm{C}$ dan kecepatan $600 \mathrm{rpm}$ selama 30 menit. Lapisan film tipis akan terbentuk kemudian hidrasi lapisan dengan fosfat buffer saline $(\mathrm{pH}$ $7.4)$ atau campuran hidroetanol $(1 \% \mathrm{~b} / \mathrm{v})$ pada 60 rpm selama 1 jam. Selanjutnya sonikasi campuran dalam 3 siklus selama 5 menit. Jika proses sonikasi telah selesai, formula dimasukkan ke dalam dan disimpan pada suhu $4^{\circ} \mathrm{C}$ (Jaiswal et al., 2016; Sultana et al., 2018).

\section{Metode klasik}

Metode ini diawali dengan melarutkan fosfolipid dan obat ke dalam etanol dan dipanaskan hingga $30^{\circ} \mathrm{C} \pm 1^{\circ} \mathrm{C}$ di dalam waterbath. Campuran kemudian ditambahkan air dengan pengadukan konstan pada 700 rpm. Suspensi vesikel etosom yang dihasilkan, selanjutnya dihomogenisasi dengan cara melewatkan melalui membran polikarbonat menggunakan pengekstrusi selama tiga siklus (Gaikwad dan Ayushi, 2017).

\section{Metode Karakterisasi Etosom}

Umumnya, setelah pembuatan etosom maka dilakukan karakterisasi untuk melihat karakteristik etosom yang telah dibuat. Terdapat beberapa metode untuk melakukan karakterisasi etosom yang dapat dilihat pada Tabel 2.

\section{Pemanfaatan Etosom dalam Sediaan Patch}

Sistem etosom bisa diaplikasikan untuk pengobatan infeksi mikroba dan virus pada kulit, antiinflamasi, analgesik dan antipiretik, pengobatan sindrom menopause, dan disfungsi ereksi (Mohanty et al., 2018). Penggunaan etosom sebagai pembawa dalam bentuk sediaan patch dapat meningkatkan penetrasi, bioavailabilitas, permeabilitas suatu agen terapeutik, dapat memperpanjang waktu pelepasan obat karena pengeluaran obat terkontrol dan konstan, serta menghindari efek samping obat jika diberikan peroral (Nagadevi et al., 2014; Liu et al., 2011). Selain itu, karena vesikel etosom berukuran nano maka penggunaan pembawa etosom dalam sediaan patch dapat memudahkan zat aktif dalam menembus barier utama kulit yaitu stratum korneum yang merupakan masalah utama dalam sistem penghantaran transdermal. Etosom meningkatkan kemampuan zat aktif dalam berpenetrasi melalui kulit sehingga sediaan patch dapat memberikan efek sistemik (Niu et al., 2019; Suryani dkk., 2017).

Berdasarkan penelitian terdahulu, 
Tabel 2. Metode Karakterisasi Etosom

\begin{tabular}{ll}
\hline \multicolumn{1}{c}{ Parameter Karakterisasi } & \multicolumn{2}{c}{ Metode } \\
\hline Morfologi permukaan/ & Visualisasi etosom dapat dilakukan menggunakan Transmission \\
visualisasi & Electron Microscope (TEM) dan Scanning Electron Microscope \\
& $($ SEM)). TEM dan SEM dapat memperlihatkan bentuk vesikel dari \\
& etosom (Patrekar dkk., 2015; Niu dkk., 2019).
\end{tabular}

Ukuran vesikel dan distribusi ukuran

Efisiensi penjerapan

Suhu transisi

Pengukuran aktivitas tegangan antar muka Kekeruhan

Tingkat deformabilitas atau elastisitas pengukuran

Zeta potensial

Studi interaksi vesikel-kulit

Interaksi fosfolipid-etanol

Kandungan obat

Studi stabilitas

Studi penetrasi

Permeasi/deposisi kulit secara in vitro
Ukuran etosom dan distribusi ukuran dilakukan secara dinamis dengan menggunakan metode Dynamic Light Scattering (DLS) dengan sistem inspeksi komputerisasi dan menggunakan instrumen Particle Size Anlyzer (PSA) (Salmannejad dkk., 2015; Nandure, dkk., 2013).

Kemampuan etosom secara efisien dalam menarik obat lipofilik dan hidrofilik dapat diukur dengan ultrasentrifugasi, metode kolom mini, sentrifugasi dan spektrofotometri fluorosense (Salmannejad dkk., 2015; Gaikwad dan Ayushi, 2017).

Suhu transisi vesikel lipid dapat ditentukan dengan menggunakan Differensial Scanning Colorimetric (DSC) (Wahid dkk., 2011).

Aktivitas tegangan antarmuka dapat diukur menggunakan du nouy ring tensiometer dengan larutan encer (Wahid dkk., 2011).

Kekeruhan dapat diukur dengan menggunakan nephelometer (Wahid dkk., 2011).

Elastsitas pengukuan etosom dapat ditentukan dengan metode ekstruksi. Formulasi etosomal diekstruksi melalui membran filter dengan diameter pori $50 \mathrm{~nm}$ (Wahid dkk., 2011).

Zeta potensial dapat diukur dengan zeta meter atau menggunakan metode Dynamic Light Scattering (DLS) (Gaikwad dan Ayushi, 2017; Wahid dkk., 2011).

Interaksi vesikel-kulit dilakukan dengan menggunakan Transmission Electron Microscopy, Confocal Laser Scanning Microscope (CSLM) atau dengan menggunakan mikroskop fluorosensi. Jika menggunakan mikroskop fluorosensi, etosom ditambahkan zat fluoresens seperti rhodamine (Gaikwad dan Ayushi, 2017; Wahid dkk., 2011).

Interaksi fosfolipid-etanol dapat diuji dengan menggunakan ${ }^{31} \mathrm{P} N \mathrm{NR}$ atau dengan Differential Scanning Calorimeter (DSC) (Gaikwad dan Ayushi, 2017; Wahid dkk., 2011).

Kandungan obat formulasi etosom diukur dengan teknik High Performance Liquid Chromatography (HPLC) atau spektorofotometri UV (Wahid dkk., 2011).

Studi stabilitas dapat dilakukan menggunakan metode Transmission Electron Microscope (TEM) atau Dynamic Light Scattering (DLS) (Gaikwad dan Ayushi, 2017; Wahid dkk., 2011).

Tingkat penetrasi kulit dari etosom dapat ditentukan menggunakan Confocal Laser Scanning Microscope (CLSM) (Wahid dkk., 2011).

Karakteristik permeasi kulit dari formulasi dapat dilakukan dengan meggunakan metode difusi franz dengan media difusi buatan atau membran biologis seperti kulit manusia bagian epidermis, kulit perut tikus, kulit perut tikus, dan kulit kelinci (Patrekar dkk., 2015; Wahid dkk., 2011); Limsuwan dkk., 2017). 
terdapat beberapa obat yang telah diformulasi dalam patch etosom yang dapat dilihat pada Tabel 3. Rakesh dan Anoop (2012) telah menyebutkan bahwa Touitou dkk telah melakukan penelitian secara in vivo untuk membandingkan efisiensi patch etosom testosteron yang telah diformulasi dengan patch transdermal testosteron yang telah dipasarkan (Testoderm ${ }^{\circledR}$ patch) pada hewan uji. Hasil penelitian yang diperoleh yaitu permeasi dari patch etosom testosteron hampir 30 kali lebih tinggi dibandingkan dengan Testoderm $®$ patch .

Hasil penelitian Nagadevi et al., 2014 juga menyatakan bahwa patch etosom Tizanidine hidroklorida menunjukkan persentase pelepasan obat yang baik, dengan demikian disimpulkan bahwa etosom adalah pembawa yang sangat menjanjikan sebagai pembawa obat khususnya sediaan patch transdermal. Penelitian Liu et al., 2011 juga menjelaskan bahwa patch etosom Ligustrazine memiliki keunggulan banyak keunggulan dibandingkan patch Ligustrazine konvensional diantaranya yaitu berdasarkan hasi uji pelepasan diperoleh kurva pelepasan in vitro dari patch etosom Ligustrazin yang konstan selama 24 jam yang menunjukkan efek pelepasan berkelanjutan yang baik serta niali AUC patch etosom Ligustrazin 2,12 kali lipat lebih besar dari pada kelompok patch Ligustrazin konvensional.

Kumar dan Patra (2020) juga melakukan penelitian mengenai patch etosom yaitu memformulasikan patch etosom Duloxetine dan diperoleh hasil yaitu peningkatan penetrasi Duloxetine serta formula patch etosom Duloxetine menunjukkan profil pelepasan obat yang diperpanjang dibandingkan sediaan konvensionalnya. Penelitian lain juga menjelaskan bahwa formulasi patch etosom Clopidogrel menunjukkan pola pelepasan yang baik serta studi karakterisasi telah menunjukkan hasil yang menjanjikan dan mengkonfirmasi bahwa formulasi patch berbasis etosom yang digunakan untuk penghantaran Clopidogrel sebagai antiplatelet sangat memungkinkan dikarenakan dapat meningkatkan bioavailabilitas Clopidogrel.

\section{Preparasi Patch Etosom}

Patch etosom dibuat secara terpisah antara patch dan etosom. Patch disiapkan setelah pembuatan etosom terlebih dahulu. Metode umum yang digunakan dalam pembuatan patch adalah metode solvent casting atau penguapan pelarut. Pembuatan patch dengan metode ini dilakukan dengan melarutkan polimer yang akan digunakan dalam pelarut yang sesuai setelah itu dilakukan penambahan enhancer. Pencampuran dilakukan menggunakan magnetic stirrer. Jika semua polimer dan enhancer telah tercampur homogen, maka suspensi etosom yang telah disiapkan sebelumnya diinkorporasikan ke dalam campuran polimer patch. Kemudian dilakukan pengadukan untuk mendapatkan campuran suspensi etosom dan larutan polimer yang homogen. Setelah terbentuk campuran homogen, dimasukkan plasticizer kemudian diaduk lagi hingga homogen. Selanjutnya, dilakukan penguapan pelarut dengan cara larutan yang telah dihasilkan dituangkan ke dalam cetakan dan ditunggu hingga kering (biasanya selama 24 jam), pada suhu ruang. Cetakan disimpan dalam desikator untuk menghilangkan kelebihan air di dalamnya (Nagadevi et al., 2014).

\section{Evaluasi Sediaan Patch Etosom}

\section{Uji organoleptik}

Pengujian organoleptik ini dilakukan secara visual untuk mengamati warna, bau, dan kondisi permukaan patch yang dihasilkan selama 24 jam. Parameter uji ini yaitu patch yang dihasilkan harus halus, transparan, dan tidak memiliki bau (Hermanto dkk., 2019; Fatmawaty dkk., 2017).

\section{Uji pH}

Uji pH dilakukan dengan cara mengukur $\mathrm{pH}$ pada permukaan patch. Persyaratan $\mathrm{pH}$ sediaan patch adalah harus sesuai dengan $\mathrm{pH}$ kulit agar tidak mengiriitasi kulit yaitu dalam rentang 5-6,5 (Hermanto dkk., 2019).

\section{Uji Ketebalan}

Uji ketebalan patch dilakukan untuk mengetahui ketebalan pada setiap sediaan dengan menggunakan jangka sorong. Parameter uji ini yaitu ketebalan patch tidak lebih dari $1 \mathrm{~mm}$ (Arifin dkk., 2019).

\section{Pengujian Bobot}

Uji ini dilakukan untuk mengetahui bobot sediaan patch. Sediaan patch diambil sebanyak 6 buah kemudian ditimbang dan dilihat variasi bobotnya. Parameter uji ini yaitu bobot patch yang diharapkan sebesar 500 mg (Arifin dkk., 2019).

\section{Pengujian kadar air}

Pengujian kadar air dilakukan menggunakan metode thermogravimetri yaitu dengan cara patch ditimbang terlebih dahulu kemudian dikeringkan di dalam oven pada suhu $105 \pm 5^{\circ} \mathrm{C}$ selama satu jam dan selanjutnya didinginkan pada desikator. Bobot patch diukur kembali. Kadar air sediaan patch dihitung menggunakan rumus berikut:

$$
\% \text { kadar air }=\frac{\text { berat awal }- \text { berat akhir }}{\text { berat awal }} \times 100 \%
$$


Tabel 3. Pemanfaatan Etosom sebagai Pembawa dalam Bentuk Sediaan Patch

\begin{tabular}{|c|c|c|c|c|}
\hline Zat Aktif & $\begin{array}{c}\text { Aktivitas } \\
\text { Farmakologis }\end{array}$ & $\begin{array}{c}\text { Permasalahan } \\
\text { Obat } \\
\text { Kon vensional }\end{array}$ & $\begin{array}{c}\text { Hasil Sediaan } \\
\text { dengan Patch } \\
\text { Etosom }\end{array}$ & Referensi \\
\hline $\begin{array}{l}\text { Tizanidine } \\
\text { Hidroklorida }\end{array}$ & $\begin{array}{l}\text { Untuk mengatasi } \\
\text { kejang otot }\end{array}$ & $\begin{array}{l}\text { Pelepasan obat } \\
\text { tidak dapat diatur }\end{array}$ & $\begin{array}{l}\text { Pelepasan obat } \\
\text { terkontrol dan } \\
\text { konstan }\end{array}$ & $\begin{array}{l}\text { Nagadevi dkk., } \\
2014\end{array}$ \\
\hline Ligustrazine & $\begin{array}{l}\text { Untuk angina } \\
\text { pektoris }\end{array}$ & $\begin{array}{l}\text { Bioavailabilitas } \\
\text { rendah }\end{array}$ & $\begin{array}{l}\text { Meningkatkan } \\
\text { penetrasi dan } \\
\text { bioavailabilitas } \\
\text { Ligustrazine }\end{array}$ & Liu dkk., 2011 \\
\hline Clopidogrel & Antiplatelet & $\begin{array}{l}\text { Bioavailabilitas } \\
\text { rendah, efek } \\
\text { samping oral, } \\
\text { frekuensi dosis } \\
\text { besar }\end{array}$ & $\begin{array}{l}\text { Meningkatkan } \\
\text { bioavailabilitas, } \\
\text { menghindari efek } \\
\text { samping serta } \\
\text { frekuensi pemberian } \\
\text { obat berkurang }\end{array}$ & $\begin{array}{l}\text { Shukla dkk., } \\
2016\end{array}$ \\
\hline Duloxetine & Antidepresan & $\begin{array}{l}\text { Pemeabilitas } \\
\text { rendah }\end{array}$ & $\begin{array}{l}\text { Meningkatkan } \\
\text { permeabilitas, } \\
\text { mengurangi } \\
\text { frekuensi dosis, } \\
\text { memperpanjang } \\
\text { pelepasan obat, dan } \\
\text { menghindari efek } \\
\text { samping obat per } \\
\text { oral. }\end{array}$ & $\begin{array}{l}\text { Kumar dan } \\
\text { Patra, } 2020\end{array}$ \\
\hline Insulin & Anti-hiperglikemia & $\begin{array}{l}\text { Sediaan injeksi } \\
\text { tidak nyaman } \\
\text { digunakan }\end{array}$ & $\begin{array}{l}\text { Meningkatkan } \\
\text { kenyamanan pasien } \\
\text { serta memberikan } \\
\text { efek terapi yang } \\
\text { lama dengan sekali } \\
\text { pemakaian }\end{array}$ & $\begin{array}{l}\text { Wahid dkk., } \\
2011\end{array}$ \\
\hline Klonazepam & Antiepilepsi & $\begin{array}{l}\text { Permeabilitas } \\
\text { buruk }\end{array}$ & $\begin{array}{l}\text { Meningkatkan fluks } \\
\text { transdermal serta } \\
\text { meningkatkan } \\
\text { permeabilitas } \\
\text { Klonazepam }\end{array}$ & $\begin{array}{l}\text { Salmannejad } \\
\text { dkk., } 2015\end{array}$ \\
\hline Testosteron & $\begin{array}{l}\text { Untuk mengatasi } \\
\text { defisiensi } \\
\text { hipogonadisme }\end{array}$ & $\begin{array}{l}\text { Bioavailabilitas } \\
\text { rendah karena } \\
\text { mengalami first } \\
\text { pass effect }\end{array}$ & $\begin{array}{l}\text { Meningkatan } \\
\text { permeasi dan } \\
\text { bioavailabilitas } \\
\text { Testosteron }\end{array}$ & $\begin{array}{l}\text { Abdulbaqi } \\
\text { dkk., } 2016\end{array}$ \\
\hline Febrifugine & Antimalaria & $\begin{array}{l}\text { Mengalami first } \\
\text { pass effect }\end{array}$ & $\begin{array}{l}\text { Terhindar first pass } \\
\text { effect dan } \\
\text { meningkatkan } \\
\text { penetrasi } \\
\text { Febrifugine }\end{array}$ & $\begin{array}{l}\text { Shen dkk., } \\
2015\end{array}$ \\
\hline
\end{tabular}


Persyaratan kadar air yang baik pada patch yaitu kurang dari 10\% (Arifin dkk., 2019).

1. Uji freeze thaw

Uji freeze thaw dilakukan untuk mengetahui stabiltas fisik sediaan patch terhadap suhu. Uji ini dilakukan sebanyak 5 siklus pada suhu $4^{\circ} \mathrm{C}$ dan $40^{\circ} \mathrm{C}$. Parameter uji ini yaitu patch tetap dalam keadaan stabil walaupun disimpan pada suhu dingin atau suhu panas (Nurmesa dkk., 2019).

\section{KESIMPULAN}

Penggunaan etosom dalam bentuk sediaan patch terbukti dapat meningkatkan penetrasi, permeabilitas dan bioavailabilitas dari suatu obat tertentu, serta dapat memperpanjang waktu pelepasan obat karena pelepasannya secara terkontrol dan konstan. Beberapa obat yang telah diformulasi menjadi bentuk sediaan patch dengan menggunakan pembawa etosom antara lain Tizanidine Hidroklorida, Ligustrazin, Clopidogrel, Duloxetin, Klonazepam, Testosteron, Febrifugine dan Insulin. Pengembangan sistem penghantaran obat berbasis etosom untuk dalam bentuk sediaan patch masih terus dikembangkan dan diteliti lebih lanjut.

\section{DAFTAR PUSTAKA}

Abdulbaqi, I.M., Darwis, Y., Khan, N.A.K., Assi, R.A., dan Khan, A.A., 2016. Ethosomal Nanocarriers: The Impact of Constituents and Formulation Techniques on Ethosomal Properties, In Vivo Studies, and Clinical Trials. International Journal of Nanomedicine, 11(1), 2279-2304.

Akib, N.I., Suryani, Halimahtussaddiyah, R., dan Prawesti, N., 2014. Preparasi Fenilbutazon dalam Pembawa Vesikular Etosom dengan Berbagai Variasi Konsentrasi Fosfatidilkolin dan Etanol. Medula, 2(1),112-118.

Alagumuthu, M., Dahiya, D., dan Nigam, P.S., 2019. Phospholipid: the Dynamic Structure Between Living and non-Living World; a Much Obligatory Supramolecule for Present and Future. AIMS Molecular Science, 6(1), 1-19.

Arifin, A., Sartini, dan Marianti, 2019. Evaluasi Karakteristik Fisik dan Uji Permeasi pada Formula Patch Aspirin Menggunakan Kombinasi Etilselulosa dengan Polivinilpirolidon. Jurnal Sains dan Kesehatan, 2(1), 40-49.

Bodade, S.S., Shaikh, K.S., Kamble, M.S., dan Chaudhari, P.D., 2013. A Study on Ethosomes as Mode for Transdermal Delivery of an Antidiabetic Drug. Drug Delivery, 20(1), 40-46.

Bragagni, M., Mennini, N., Maestrelli, F., Cirri, M., dan Mura, P., 2012. Comparative Study of Liposomes, Transfersomes and Ethosomes as Carriers for Improving Topical Delivery of Celecoxib. Drug Delivery, 19(7), 354-361.

Dave, V., Kumar, D., Lewis, S., dan Paliwal, S., 2010. Ethosome for Enhanced Transdermal Drug Delivery of Aceclofenac. International Journal of Drug Delivery, 2(1), 81-92.

Ermawati, D.E., dan Prilantari, H.U., 2019. Pengaruh Kombinasi Polimer Hidroksipropilmetilselulosa dan Natrium Karboksimetilselulosa terhadap Sifat Fisik Sediaan Matrix-based Patch Ibuprofen. Journal of Pharmaceutical Science and Clinical Research, 2(1), 109-119.

Fatmawaty, A., Nisa, M., Irmayani, dan Sunarti, 2017. Formulasi Patch Ekstrak Etanol Daun Murbei (Morus Alba L.) dengan Variasi Konsentrasi Polimer Polivinil Pirolidon dan Etil Selulosa. Journal of Pharmaceutical and Medicinal Sciences, 2(1), 17-20.

Fiume, M.M., Bergfeld, W.F., Belsito, D.V, Hill, R.A., Klaassen, C.D., Liebler, D., Jr, J.G.M., Shank, R.C., Slaga, T.J., Snyder, P.W., dan Andersen, F.A., 2012. Safety Assessment of Propylene Glycol, Tripropylene Glycol, and PPGs as Used in Cosmetics. International Journal of Toxicology, 31(2), 245S-260S.

Gaikwad, Kaveri A.B.S., dan Somwanshi, A.P., 2017. Ethanolic Vesicles: A Novel Approach to Enhance Transdermal Drug Delivery. Indo American Journal of Pharmaceutical Research, 7(1), 7440-7450.

Hendradi, N., Isnaeni, N., Fridayanti, A., dan Pujianti, E., 2011. Optimasi Sediaan Transdermal Patch Natrium Diklofenak Tipe Matriks. Jumal Farmasi Indonesia, 5(3), 112-119.

Hermanto, F.J., Lestari, F., Hermawati, C., dan Nurviana, V., 2019. Evaluasi Sediaan Patch Daun Handeulem (Graptophyllum griff L.) sebagai Penurun Panas. Jurnal Kesehatan Bakti Tunas Husada: Jurnal IImu-IImu Keperawatan, Analis Kesehatan dan Farmasi, 19(2), 208-217.

Jaiswal, P.K., Kesharwani, S., Kesharwani, R., dan Patel, D.K., 2016. Ethosome: A New Technology Used as Topical and Transdermal Delivery System. Journal of Drug Delivery and Therapeutics, 6(3), 6-17.

Kumar, E., dan Patra, N., 2020. Development Characterization Optimization of Ethosome Containing Duloxetine for 
Transdermal Delivery. International Journal of Pharmaceutical Sciences and Research, 11(2), 652-659.

Limsuwan, T., Boonme, P., Khongkow, P., dan Amnuaikit, T., 2017. Ethosomes of Phenylethyl Resorcinol as Vesicular Delivery System for Skin Lightening Applications. BioMed Research International, 2(3), 1-12.

Liu, X., Liu, H., Liu, J., He, Z., Ding, C., Huang, G., Zhou, W., dan Zhou, L., 2011. Preparation of a Ligustrazine Ethosome Patch and its Evaluation in Vitro and in Vivo. International Journal of Nanomedicine, 6(1), 241-247.

Ma, H., Guo, D., Fan, Y., Wang, J., Cheng, J., dan Zhang, X., 2018. Paenol-Loaded Ethosomes as Transdermal Delivery Carriers: Design, Preparation and Evaluation. Molecule, 23(7), 1-15.

Mohanty, D., Mounika, A., Bakshi, V., Haque, A.M., dan Sahoo, K.C., 2018. Ethosomes: A Novel Approach for Transdermal Drug Delivery. International Journal of ChemTech Research, 11(8), 219-226.

Nagadevi, B., Kumar, K.S., Venkanna, P., dan Prabhakar, D., 2014. Formulation and Characterisation of Tizanidine Hydrochloride Loaded Ethosomes Patch. International Journal of Pharmacy and Pharmaceutical Sciences, 6(4), 199-205.

Nandure, H.P., Prashant, P., Prabhanjan, G., dan Vidya, L., 2013. Ethosome: A Novel Drug Carrier International Journal of Pharmaceutical Sciences and Allied Research (Impact Factor 3.181). International Journal of Pharmaceutical Research \& Allied Sciences, 2(3), 18-30.

Niu, X.Q., Zhang, D.P., Bian, Q., Feng, X.F., Li, H., Rao, Y.F., Shen, Y.M., Geng, F.N., Yuan, A.R., Ying, X.Y., dan Gao, J.Q., 2019. Mechanism Investigation of Ethosomes Transdermal Permeation. International Journal of Pharmaceutics, 2(1), 1-13.

Nurmesa, A., Nurhabibah, dan Najihudin, A., 2019. Formulasi dan Evaluasi Stabilitas Fisik Patch Transdermal Alkaloid Nikotin Daun Tembakau (Nicotiana tobacum Linn) dengan Variasi Polimer dan Asam Oleat. Jurnal Penelitian Farmasi Herbal, 2(1), 1-8.

Pandey, V., Golhani, D., dan Shukla, R., 2015. Ethosomes: Versatile Vesicular Carriers for Efficient Transdermal Delivery of Therapeutic Agents. Drug Delivery, 22(8), 988-1002.

Patrekar, P.V, Inamdar, S.J., Mali, S.S., Mujib, M.T., Ahir, A.A., dan Hosmani A.H., 2015. Ethosomes As Novel Drug Delivery System: A Review. The Pharma
Innovation Journal, 4(49), 10-21.

Prabhakara, P., Koland, M., Vijaynarayana, K., Harish N.M., Shankar G., Mohd G.A., Narayana C.R., dan Satyanarayana D., 2010. Preparation and Evaluation of Transdermal Patches of Papaverine Hydrochloride. International Journal of Research in Pharmaceutical Sciences, 1(3), 259-266.

Prasanthi, D., dan Lakshmi, P.K., 2012. Development of Ethosomes with Taguchi Robust Design-Based Studies for Transdermal Delivery of Alfuzosin Hydrochloride. International Current Pharmaceutical Journal, 1(11), 370-375.

Purnamasari, N., Alatas, F., dan Gozali, D., 2019. Formulasi dan Evaluasi Transdermal Patch Kalium Diklofenak. Jurnal IImiah Farmasi, 7(1), 43-48.

Rahim, F., Deviarny, C., Yenti, R., dan Ramadani, P., 2016. Formulasi Sediaan Patch Transdermal dari Rimpang Rumput Teki (Cyperus Rotundus L.) untuk Pengobatan Nyeri Sendi pada Tikus Putih Jantan. Scientia: Jurnal Farmasi Dan Kesehatan, 6(1), 1-6.

Rakesh, R., dan Anoop, K.R., 2012. Ethosomes for Transdermal and Topical Drug Delivery. International Journal of Pharmacy and Pharmaceutical Sciences, 4(3), 17-24.

Ramadhani, U.K.S., Djajadisastra, J., dan Iskandarsyah, I., 2017. Pengaruh Polimer dan Peningkat Penetrasi Terhadap Karakter Penetrasi Matriks Sediaan Patch Transdermal Karvedilol. Jurnal IImu Kefarmasian Indonesia, 15(2), 120-127.

Ramadon, D., dan Mun'im, A., 2016. Pemanfaatan Nanoteknologi dalam Sistem Penghantaran Obat Baru untuk Produk Bahan Alam. Jurnal IImu Kefarmasian Indonesia, 14(2), 118-127.

Salmannejad, F., Ghari, T., dan Toliyat, T., 2015. Formulation and Evaluation of Ethosomes for Transdermal Delivery of Clonazepam. International Journal of Biosciences, 6(5), 308-316.

Shen, S., Liu, S.Z., Zhang, Y.S., Du, M.B., Liang, A.H., Song, L.H., dan Ye, Z.G., 2015. Compound Antimalarial Ethosomal Cataplasm: Preparation, Evaluation, and Mechanism of Penetration Enhancement. International Journal of Nanomedicine, 10(1), 4239-4253.

Shukla, T., Verma, A., Upmanyu, N., Mishra, S. S., dan Shilpi, S., 2016. Development and Characterization of Clopidogrel-loaded Ethosomal Transdermal Patch for Antiplatelet Effect. Asian Journal of 
Pharmaceutics, 10(4), S680-S686.

Singh, A., dan Bali, A., 2016. Formulation and Characterization of Transdermal Patches for Controlled Delivery of Duloxetine Hydrochloride. Journal of Analytical Science and Technology, 7(1), 1-13.

Sultana, B., Rajak, P., Bhuyan, B., Patra, E., Baruah, A., dan Paul, D., 2018. Therapeutic Potential of Herbal Ethosome in Applied Nanotechnology. Saudi Journal of Medical and Pharmaceutical Sciences, 4(4), 443-454.

Suryani, Musnina, W.O.S., dan Anto, A.S., 2017. Optimasi Formula Matriks Patch Transdermal Nanopartikel Teofilin dengan Menggunakan Metode Simplex Lattice Design (SLD). Majalah Farmasi, Sains, dan Kesehatan, 3(1), 26-32.

Thadanki, M., dan Babu, A.K., 2015. Review on Ethosomes: A Novel Approach of Liposomes. International Journal of Phaarmacy and Life Sciences, 6(1), 4171-4176.

Wahid, A.A., Ravouru, N., dan Lakshman, S.R., 2011. Ethosomes: A Tool for Transdermal Drug Delivery, Current Trends in Biotechnology and Pharmacy, 5(1), 972-981.

Wusnah, Bahri, S., dan Hartono, D., 2016. Proses Pembuatan Bioetanol dari Kulit Pisang Kepok (Musa acuminata B.C) secara Fermentasi. Jurnal Teknologi Kimia Unimal, 5(1), 48-56.

Zahid, S. R., Upmanyu, N., Dangi, S., Ray, S. K., Jain, P., dan Parkhe, G., 2018. Ethosome: A Novel Vesicular Carrier for Transdermal Drug Delivery. Journal of Drug Delivery snd Therapeutics, 8(6), 318-326. 